\title{
A Comparative Study of How to Renovate Historical Fabrics in the UK, France, the USA and Iran (Shiraz)
}

\author{
Tahereh $\mathrm{Nasr}^{1}$ \\ ${ }^{1}$ Department of Architecture, Shiraz Branch, Islamic Azad University, Shiraz, Iran \\ Correspondence: Tahereh Nasr, Ph.D.; Assistant Professor, Department of Architecture, Shiraz Branch, Islamic \\ Azad University, Shiraz, Iran. E-mail: nasr@iaushiraz.ac.ir; nasr.soha@gmail.com
}

\author{
Received: March 1, 2016 Accepted: September 19, 2016 Online Published: November 30, 2016 \\ doi:10.5539/jsd.v9n6p168 URL: http://dx.doi.org/10.5539/jsd.v9n6p168
}

\begin{abstract}
Restoration and renovation of the historical fabric of towns is one of the methods of intervention in towns with historical fabrics and old buildings that means continuous and conscious act for modernization, prevention from erosion and wear, longevity of historical buildings and fabrics of the towns, which are carried out aiming at a new function as appropriate to the needs of the daily life.

The record of restoration of the historical fabric of the towns in advanced counties is about two countries old, but the restoration and improvement of the historical fabric of towns separately and independent from historical buildings as a live, dynamic urban element was never paid attention by congresses and scientific centers before the Second World War. After the Second World War, restoration and reconstruction was paid attention again and was discussed in academic centers. That was while construction operations were under way in most European towns rapidly and intensively and no enough time was there for their study. The present article, while reviewing the world laws and enactments on urban restoration, has a look on different kinds of renovation in urban fabrics. What is important is the economic feasibility of renovation in the areas under study.

The present article is an effort towards review of the literature on restoration and innovation of historical urban fabrics based on the universal activities.
\end{abstract}

The purpose of this study is explanation of the components being paid attention in renovation of the old urban fabrics.

An analytical - comparative review of the experience gained in developed countries, on the one hand, and developing countries, on the other hand, could provide a guide toward development of effective solutions for renovation of historical spaces in towns. Analysis and examination of the process of the influence of modern western architectural, urban development and urban restoration on the modern Iranian architecture and urban development are among the achievements of such a study.

The research methodology, considering exploration of the form of the Iranian town is descriptive - analytical and the method of collecting data is field work and documentation

"The content structure of the study" is supported by the process of determination and introduction of efficient policies and strategies in traditional and historical fabrics. Strategies such as creation of new economic demands, environmental improvements, preservation and safeguarding of the historical nature of the quarter with physical restoration, development of criteria for functional design and renovation are among other notable subjects in this project.

The findings of the study show that, the historical neighborhoods of towns usually serve as autonomous functional areas, and, therefore, paying attention to them must be made in the context and the general fabric of the town and the relevant districts. Renovation, which is nothing but returning vitality and activity to the areas, is a dynamic, powerful process. Considering the above- mentioned items, one could say that the process has had different degrees in different areas. A successful renovation must show itself, in physical, economic and social aspects as well.

The results show the physical improvement of the town by paying attention to the physical components of the urban indentify. Also, one should attend to creation of cognitive and aesthetic values aiming at providing the readability and upgrading the mental image of the town when innovating the old fabrics. 
Keywords: universal laws and enactments on urban restoration, town renovation, identity, Iran, Shiraz

\section{Introduction}

The identity of each period is determined by characteristics and advantages of that period relative to that of the previous period. When we speak of the town's identity, we mean distinction of towns from one another. The plausible thing is the shared and distinctive points of towns jointly. What is imagined as an image in the mind of people is due to the spatial organization of the town knowing and understanding the structure and the backbone of towns, the spatial organization, of towns and making efforts for their preservation and renovation have led to preservation of values inherent in towns, knowing the identity, and its effective components as regards the town's form, is a prerequisite for understanding of managers, urban planners, decision - makers and anybody who plays a role in the town development so as a town is made the identity traits of which are desired and dependable.

The question that is raised here is: "what factors" contribute to renovation of old urban fabrics and what are the strategies that could be used in regularization of old urban fabrics?

Therefore, the current article has a look at the concept of renovation in urban development, with the requirement that the concept of the town's identity be treated theatrically and practically.

\subsection{The Objectives of the Study}

Studying the reflection of paying attention to the concept of "identity" in towns

The components attended to in regeneration of old urban fabrics are discussed by studying the solutions that could be used for regularization of old urban fabrics.

\subsection{The Research Methodology}

The method that will be used in this study, considering exploration of typical urban fabrics of some European and American countries as well as Shiraz town in Iran, is descriptive - analytical and the method of collection of data is field work and documentation.

\section{Historical Review}

Restoration of the historical fabrics of towns in European countries was begun from early $19^{\text {th }}$ century with traditional styles non- systematically. In the 1960's, theories and scientific methods of urban design were used and by scientific activities and practical endeavors, new technologies were used in restoration of historical fabrics of towns.

The policies being used in advanced countries in 1950's were reconstruction, in 1960's they were regeneration, in 1970s they were regeneration, in 1980s they were redevelopment and in 1990s they were renovation.

In the Europe, policies and objectives such as attracting active participation of local people in large urban restoration projects, regeneration of housing units with time, conversion of useless spaces into open public spaces, coordination of the compositions of the new and the old fabrics, granting a new function to the building, regularization of commercial activities, shopping centers and making recreational places, reconstruction and careful preservation of facades, restoration of single buildings, modernization of the inner space of buildings, inspiration from the old fabric in the new construction, demolition of buildings that lack any valued preservation and safeguarding the buildings on the path, improvement in the structural situation of the old fabric, using potentials of the street, the square and the green areas textures, prevention from imparting any damage to the foundation and the organization of the old fabric, interaction of the old elements and new spaces in the backbone of the old town and relocation of intervening industries to places beyond the town, are among the most important issues being seriously paid attention in urban restoration of European towns.

In the UK towns, with policies and strategies such as increase in private investment along with public resources, physical improvement and upgrading the environmental quality, business development, functional renovation towards creation of tourism potential and urban renovation, enhancement of the economy of the central district of the town and satisfying the residents' expectations, improvement of the physical context of the central districts of the town and constructing a more attractive environment, etc., attempted improvement and restoration of their historical fabrics.

Also, universal resolutions and enactments on urban restoration, which have been in force since 1931, paid attention to historical urban fabrics, and all of them emphasized on identification and regeneration of urban fabrics.

Below, some of universal resolutions and enactments on urban restoration are listed and the main objectives of some of them are given. 


\section{Universal Resolutions and Enactments on Urban Restoration}

Athena congress 1931, the Hague congress 1954, Gobineau congress 1960, UNESCO'S Recommendation 1962, Venice congress 1964, Kyoto's measure 1967, Paris summit 1968, Roma congress 1972, Paris Treaty 1972, Budapest declaration 1972, treaty on preservation of universal cultural Heritage 1973, European Council 1975, Bologna congress 1975, Rotenberg declaration 1975, Amsterdam declaration 1975, Nairobi Recommendation 1976, Florence charter 1982, Trinidad Declaration 1982, Dresden declaration 1982, Roma declaration 1983, Washington charter 1987, Lausanne declaration, Maastricht Treaty, Colombo Instruction, Nara Document 1994, Saint Antonio declaration 1996, Sofia Charter 1996, Bora charter 1996, Stockholm Declaration 1998, ICOMOS declaration 1998, Mexico city declaration 2000.

Table 1. Objectives of universal congresses and declarations on urban restoration

\begin{tabular}{|c|c|}
\hline $\begin{array}{c}\text { Declaration or } \\
\text { Congress }\end{array}$ & Objectives \\
\hline Athena congress & $\begin{array}{l}\text { - Improving valuable single buildings by reconstruction method and the suggested museum - functional } \\
\text { use } \\
\text { - Valuing artistic, not historical evidence, preservation of the architectural value, provided that the least } \\
\text { detriment will be imported on the four main functions of the town }\end{array}$ \\
\hline Paris Treaty & $\begin{array}{l}\text { - International cooperation of states for protection of the world's cultural heritage, at the level of all } \\
\text { member states. With the method of improvement and regeneration, with museum use } \\
\text { - } \quad \text { All inclusive protection of the world heritage, ensuring cooperation between the member states }\end{array}$ \\
\hline $\begin{array}{l}\text { treaty on preservation } \\
\text { of universal cultural } \\
\text { Heritage }\end{array}$ & $\begin{array}{l}\text { - Improving the form, the space and the function at the level of cultural, historical and natural places on a } \\
\text { universal scale, with the method of improvement and regeneration, emphasizing on continuance of historical } \\
\text { use } \\
\text { - Paying attention to the international role of habitats, encouraging the states to preserve and register the } \\
\text { historical and natural habitats, and encouragement of international cooperation }\end{array}$ \\
\hline & $\begin{array}{l}\text { - Improvement of form and function at the town level, with the method of improvement, regeneration and } \\
\text { reconstruction and modernization use } \\
\text { - Providing the intervention plan in the comprehensive urban plans, paying attention to the role of the } \\
\text { work or the fabric on a national and global scale. } \\
\text { - Passing the required laws and considering the public budget for operationalizing the theories, } \\
\text { participation of all forces in the community, extension of education, paying attention to the fabric being } \\
\text { restored as the main objective of urban planning, and provision of solutions as appropriate for reduction in } \\
\text { the local population relocation }\end{array}$ \\
\hline $\begin{array}{l}\text { Stockholm } \\
\text { Declaration }\end{array}$ & $\begin{array}{l}\text { - Development and granting rights to communities bearing cultural and historical heritage, the right of } \\
\text { attestation and stating the genuineness of the cultural heritage, the right to express individual cultural identity } \\
\text { in the human family, the right to a better understanding of the heritage of the self and others, the right to } \\
\text { appropriate and smart use of the common heritage, the right to participate in making decisions for } \\
\text { preservation of the heritage and its values and the right to form support associations and upgrade the cultural } \\
\text { heritage at the level of all communities bearing cultural heritage with the method of improvement and } \\
\text { regeneration with modernization use } \\
\text { - Respecting the matter of protection and enrichment of cultural variety throughout the world, increasing } \\
\text { people's participation, coordination of protection with development, developing criteria and legal standards } \\
\text { for protection and sustainable development }\end{array}$ \\
\hline England & $\begin{array}{l}\text { - The legal system of this country is non- written, and based on laws, tradition usage, or judicial } \\
\text { processes. There are direct democracy traditions in them. Some research and reports of state commissions } \\
\text { have been provided from } 1960 \text { onwards, and the establishment of public and popular counselling mechanisms } \\
\text { and participation of citizens in local government are their tendencies } \\
\text { - Protection and proper management of local heritage as a part of modern life, the historical monument } \\
\text { and a part of the cultural vision at the local and native level with the method of improvement and } \\
\text { modernization use }\end{array}$ \\
\hline $\begin{array}{l}\text { Mexico } \\
\text { declaration }\end{array}$ & $\begin{array}{l}\text { Education for protection and adaptation to the standards of modern life, creation of a regional network } \\
\text { for exchange of information and experience, extensive and continued protection, using various specialties and } \\
\text { obtaining financial, administrative and technical assistance from the officials. As you see, the main objective } \\
\text { of the declarations is paying attention to adaptation of historical urban fabrics to the modern conditions. } \\
\text { Therefore, improvement and regeneration of urban fabrics have been in the order. }\end{array}$ \\
\hline
\end{tabular}


So that it can be seen, the overall objective statements of historical urban fabric adapted to contemporary conditions. Urban renewal and regeneration of tissues has been considered.

\subsection{Review of Some Theories of Scholars Concerning "Regeneration" of Old Fabrics}

In table 2, important points of theories of some scholars of urban development about urban protection and restoration are stated.

Table 2. Some theories of urban development scholars concerning regeneration of old fabrics

\begin{tabular}{|c|c|}
\hline The Scholar & Important points of his theory \\
\hline $\begin{array}{l}\text { Eugen Violet le Duk., } \\
\qquad(1814-1879)\end{array}$ & $\begin{array}{l}\text { The building must be reconstructed in its genuine form and what that has been added to it with } \\
\text { time must be removed. Le Duke's aim of intervening in historical fabrics, is regeneration of the } \\
\text { form, and, consequently, improvement in the function }\end{array}$ \\
\hline $\begin{array}{l}\text { Camllo Boito, } \\
(1836-1914)\end{array}$ & $\begin{array}{l}\text { Blowing a new spirit into the old form, leads to regeneration of historical buildings and } \\
\text { compounds. Therefore, injection of new function into old buildings could lead to their renovation. } \\
\text { He knows regeneration of activities and economic boom as a necessity in the old fabric of towns }\end{array}$ \\
\hline $\begin{array}{l}\text { Luca Beltrami, } \\
\text { (1845-1933) }\end{array}$ & $\begin{array}{l}\text { Belonging of a building to the urban environment, means that no building is meaningful per se and } \\
\text { it is defined only through its surrounding environment }\end{array}$ \\
\hline $\begin{array}{l}\text { Leonardo Benevolo, } \\
\qquad(\mathbf{1 9 3 3 )}\end{array}$ & $\begin{array}{l}\text { Historical evolution is a vital fact, considering the stages of urban development. The purpose of } \\
\text { intervention in the old fabric, is improving its form and the conditions of living of its residents }\end{array}$ \\
\hline $\begin{array}{l}\text { Ludvico Quaroni, } \\
\qquad(1911-1987)\end{array}$ & $\begin{array}{l}\text { Urban restoration is a multifaceted thing, including all economic, physical aspects, etc., } \\
\text { regeneration of historical fabrics from various aspects, the purpose of intervention in old fabrics is } \\
\text { improving their functions while respecting their live, dynamic form }\end{array}$ \\
\hline $\begin{array}{l}\text { Terry Farrel, } \\
\qquad(1938)\end{array}$ & $\begin{array}{l}\text { Historical buildings and compounds are a treasure of beliefs and memories of the past generations. } \\
\text { Trust on the past, is the light for the path of present. Rejection of demolition and reconstruction, } \\
\text { participation of people in restoration, compatibility between old and new buildings }\end{array}$ \\
\hline $\begin{array}{l}\text { Aldo Rossi, } \\
\text { (1931-1997) }\end{array}$ & $\begin{array}{l}\text { Historical monuments containing thoughts and works of various generations of the past historical } \\
\text { monuments play a basic role in creation of the identity of towns. The purchase of intervention in } \\
\text { old fabrics is preservation of the form of historical monuments and saving the memories of various } \\
\text { generations of the past in it. }\end{array}$ \\
\hline $\begin{array}{l}\text { Constantine Doxiadis, } \\
\qquad(1913-1975)\end{array}$ & $\begin{array}{l}\text { The urban restoration being beyond and above physical and structural restoration, urban restoration } \\
\text { as an objective for renovation of the urban space }\end{array}$ \\
\hline $\begin{array}{l}\text { Richard Ragers, } \\
\text { (1933) }\end{array}$ & $\begin{array}{l}\text { Flexibility, adaptability to the surrounding space, humanism, stability, temporal continuity with } \\
\text { stress on some effects of the past, communication between people and the space, application of } \\
\text { technology in public spaces by paying attention to the urban background, effective presence of } \\
\text { man in the space }\end{array}$ \\
\hline $\begin{array}{l}\text { Renzo Piano, } \\
\text { (1937) }\end{array}$ & $\begin{array}{l}\text { Making a balance between the old and the new, man and technology, technique and art: continuity } \\
\text { in common memories from the past to the future, communication between man and nature, quarter } \\
\text { and town, people and environment, for providing acquaintance, being responsible towards the } \\
\text { community and the town. }\end{array}$ \\
\hline
\end{tabular}

One fact that has been significant in all theories is paying attention to the man and his presence in the urban fabric after its regeneration. In other words, the spatial dynamism after regeneration is the purpose. Therefore, just physical regeneration is not enough, but regeneration of the old fabric is significant as well.

\section{How One Should Innovate Historical Urban Quarters?}

One should note that the wearing of buildings and quarters shows itself in the inequality in "services provided by 
the fabric and the needs of today". Regeneration entails adaptation to this inequality. Maybe that inequality is rooted in the physical fabric of economic activities in the fabric. Regeneration as regards economic activity could be made through changed in use or creating alternative activities, which itself is broadly called, "functional regeneration", physical regeneration is achieved only in the field of general form that is preserved well and at the same time, is attractive.

At first, the policies that were being implemented for protection of historical quarters of towns were based on retrospection and thus, such policies, made the future of quarters according to their past history any effort to innovate historical quarters of towns must consider the conditions and the reactions as well, since in the form of these changes, the protective and control affairs of the zones leads to constraints. Balancing the economic matters and environmental conditions is debatable. Paying attention to the process of protection, maintenance and improvement of historical quarters in towns, the dimensions of urban design and urban regeneration is much important (Tiesdell, 1996).

\section{Universal Examples and Experiences of Urban Restoration}

The universal examples and experiences of urban restoration that are investigated, have been chosen with the purpose of paying attention to the economic, social, cultural, physical, travel and transportation, urban facilities and equipments, the way of planning, taking action and the way of intervention.

Table 3. Types of regeneration of historical fabrics in the samples under study in the UK, France and USA

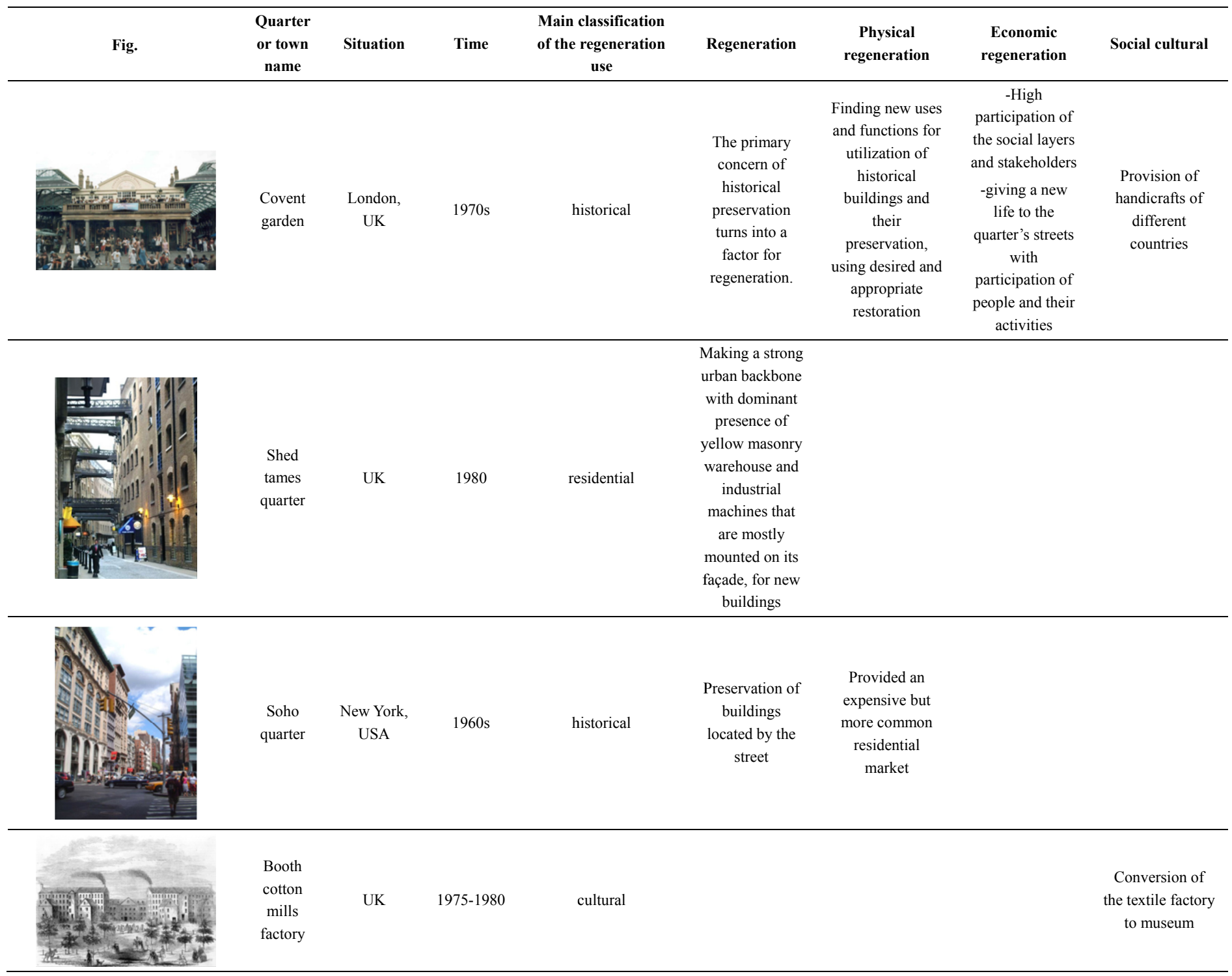




\begin{tabular}{|c|c|c|c|c|c|c|c|c|}
\hline 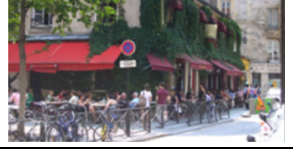 & $\begin{array}{l}\text { Ma rise } \\
\text { quarter }\end{array}$ & Paris & 1960’s & residential & & Multiple uses & lively & \\
\hline in & $\begin{array}{l}\text { Temple } \\
\text { bar }\end{array}$ & UK & 1992 & $\begin{array}{l}\text { Historical, common } \\
\text { land use }\end{array}$ & & $\begin{array}{l}\text { Common land } \\
\text { use, } \\
\text { encouragement } \\
\text { of uses in active } \\
\text { parts such as } \\
\text { retailers, clubs, } \\
\text { galleries and } \\
\text { other cultural } \\
\text { facilities to help } \\
\text { the streets and } \\
\text { making economic } \\
\text { progress }\end{array}$ & $\begin{array}{l}\text { Encouragement } \\
\text { of uses of active } \\
\text { parts for the } \\
\text { quarter's security }\end{array}$ & \\
\hline 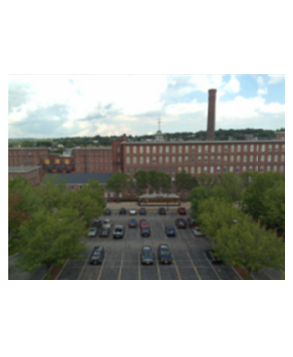 & $\begin{array}{l}\text { Booth } \\
\text { mills } \\
\text { round } \\
\text { the clock } \\
\text { park }\end{array}$ & UK & $1980 \mathrm{~s}$ & Historical-cultural & & & & $\begin{array}{c}\text {-Conversion of } \\
\text { industrial } \\
\text { buildings into } \\
\text { museum and } \\
\text { library } \\
\text {-holding art and } \\
\text { handicraft } \\
\text { exhibitions, } \\
\text { concerts, and } \\
\text { urban festivals }\end{array}$ \\
\hline 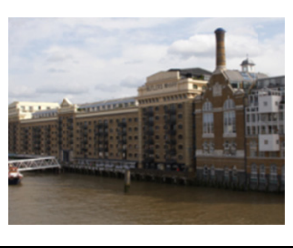 & $\begin{array}{l}\text { Butlers } \\
\text { wharf }\end{array}$ & UK & 1968 & Industrial-commercial & & & $\begin{array}{l}\text { Liveliness and } \\
\text { dynamism of the } \\
\text { residential area } \\
\text { by creation of art } \\
\text { galleries, } \\
\text { restaurants and } \\
\text { stores by them }\end{array}$ & $\begin{array}{l}\text { Conversion of } \\
\text { buildings of the } \\
\text { industrial age } \\
\text { into residential } \\
\text { ones }\end{array}$ \\
\hline 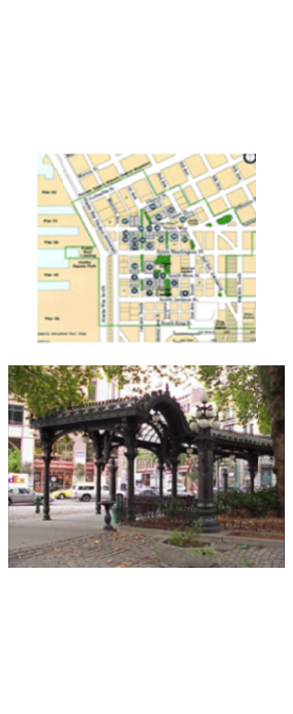 & $\begin{array}{l}\text { Pioneer } \\
\text { square }\end{array}$ & $\begin{array}{c}\text { Seattle, } \\
\text { Washington }\end{array}$ & $1970 \mathrm{~s}$ & historical & $\begin{array}{l}\text {-extension of the } \\
\text { protected zone } \\
\text { and supervising } \\
\text { the land use in } \\
\text { the quarter } \\
\text {-passing the Act } \\
\text { of preserving the } \\
\text { minimum } \\
\text { residues to } \\
\text { prevent } \\
\text { demolitions that } \\
\text { were made by } \\
\text { negligence } \\
\text { Re-surfacing of } \\
\text { the streets } \\
\text {-construction of } \\
\text { two new city } \\
\text { parks with } \\
\text { federal budget in } \\
\text { the quarter }\end{array}$ & $\begin{array}{l}\text {-Granting bank } \\
\text { loans for } \\
\text { regeneration of } \\
\text { historic areas } \\
\text {-construction of } \\
\text { pedestrian } \\
\text { markets with } \\
\text { rows of trees and } \\
\text { several outdoor } \\
\text { restaurants and } \\
\text { coffee shops } \\
\text { along Occidental } \\
\text { street }\end{array}$ & $\begin{array}{l}\text {-giving identity } \\
\text { and vitalizing the } \\
\text { zone's space } \\
\text {-creating a new } \\
\text { bus line called, } \\
\text { "taking on the } \\
\text { magic rug" } \\
\text { throughout the } \\
\text { suburb quarter } \\
\text { for more access } \\
\text { to pioneer square } \\
\text {-construction of } \\
\text { kingdom stadium }\end{array}$ & \\
\hline
\end{tabular}

The following results have been obtained in this study: 
Table 4. Paying attention to the "regeneration" components in the samples under study

\begin{tabular}{|c|c|c|c|c|c|c|c|c|c|c|}
\hline \multirow[t]{2}{*}{ No. } & \multicolumn{2}{|c|}{$\begin{array}{l}\text { Characteristics of the } \\
\text { sample under study } \\
\text { (developed countries) }\end{array}$} & \multicolumn{4}{|c|}{ Main regeneration classification } & \multicolumn{4}{|c|}{ Type of regeneration } \\
\hline & $\begin{array}{c}\text { Building } \\
\text { name }\end{array}$ & Situation & Historical & Cultural & Residential & $\begin{array}{l}\text { Industrial - } \\
\text { commercial }\end{array}$ & Physical & Economic & Social & Cultural \\
\hline 1 & $\begin{array}{l}\text { Covent } \\
\text { garden }\end{array}$ & London, UK & $\bullet$ & & & $\bullet$ & $\bullet$ & $\bullet$ & $\bullet$ & • \\
\hline 2 & $\begin{array}{l}\text { Soho } \\
\text { quarter }\end{array}$ & $\begin{array}{c}\text { New York, } \\
\text { USA }\end{array}$ & $\bullet$ & & & & $\bullet$ & $\bullet$ & $\bullet$ & • \\
\hline 3 & $\begin{array}{l}\text { Booth } \\
\text { cotton } \\
\text { mills } \\
\text { factory }\end{array}$ & UK & & $\bullet$ & & & • & & & $\bullet$ \\
\hline 4 & $\begin{array}{l}\text { Ma rise } \\
\text { quarter }\end{array}$ & Paris & & & $\bullet$ & & $\bullet$ & $\bullet$ & $\bullet$ & \\
\hline 5 & Temple bar & UK & $\bullet$ & & & & $\bullet$ & $\bullet$ & $\bullet$ & \\
\hline 6 & $\begin{array}{c}\text { Booth } \\
\text { mills } \\
\text { round the } \\
\text { clock park }\end{array}$ & UK & $\bullet$ & $\bullet$ & & & $\bullet$ & & & • \\
\hline 7 & $\begin{array}{l}\text { Butlers } \\
\text { wharf }\end{array}$ & UK & $\bullet$ & & & $\bullet$ & $\bullet$ & & $\bullet$ & • \\
\hline 8 & $\begin{array}{l}\text { Pioneer } \\
\text { square }\end{array}$ & $\begin{array}{c}\text { Seattle, } \\
\text { Washington }\end{array}$ & $\bullet$ & & & & $\bullet$ & • & • & \\
\hline 9 & $\begin{array}{l}\text { Shed } \\
\text { tames } \\
\text { quarter }\end{array}$ & UK & & & $\bullet$ & & $\bullet$ & & & \\
\hline
\end{tabular}




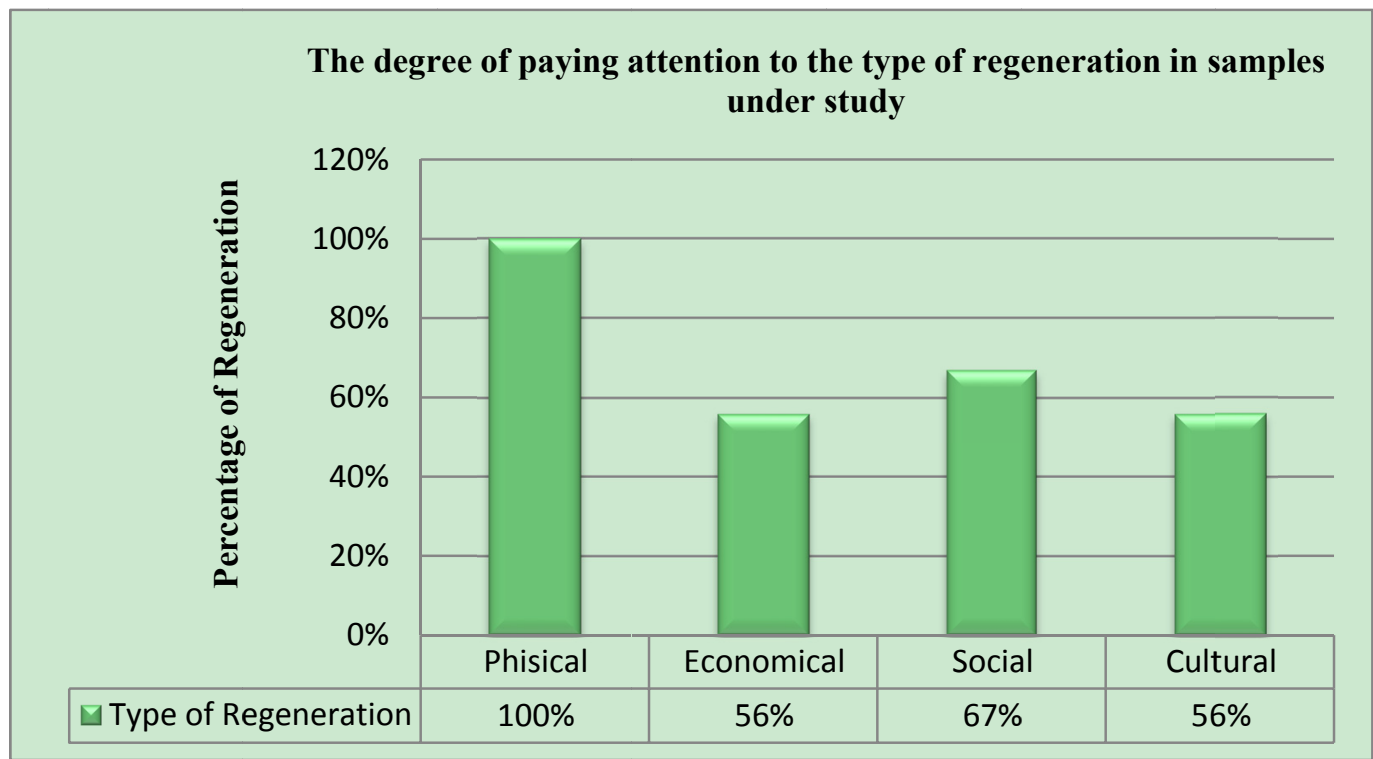

Figure 1. The degree of paying attention to the type of regeneration in samples under study

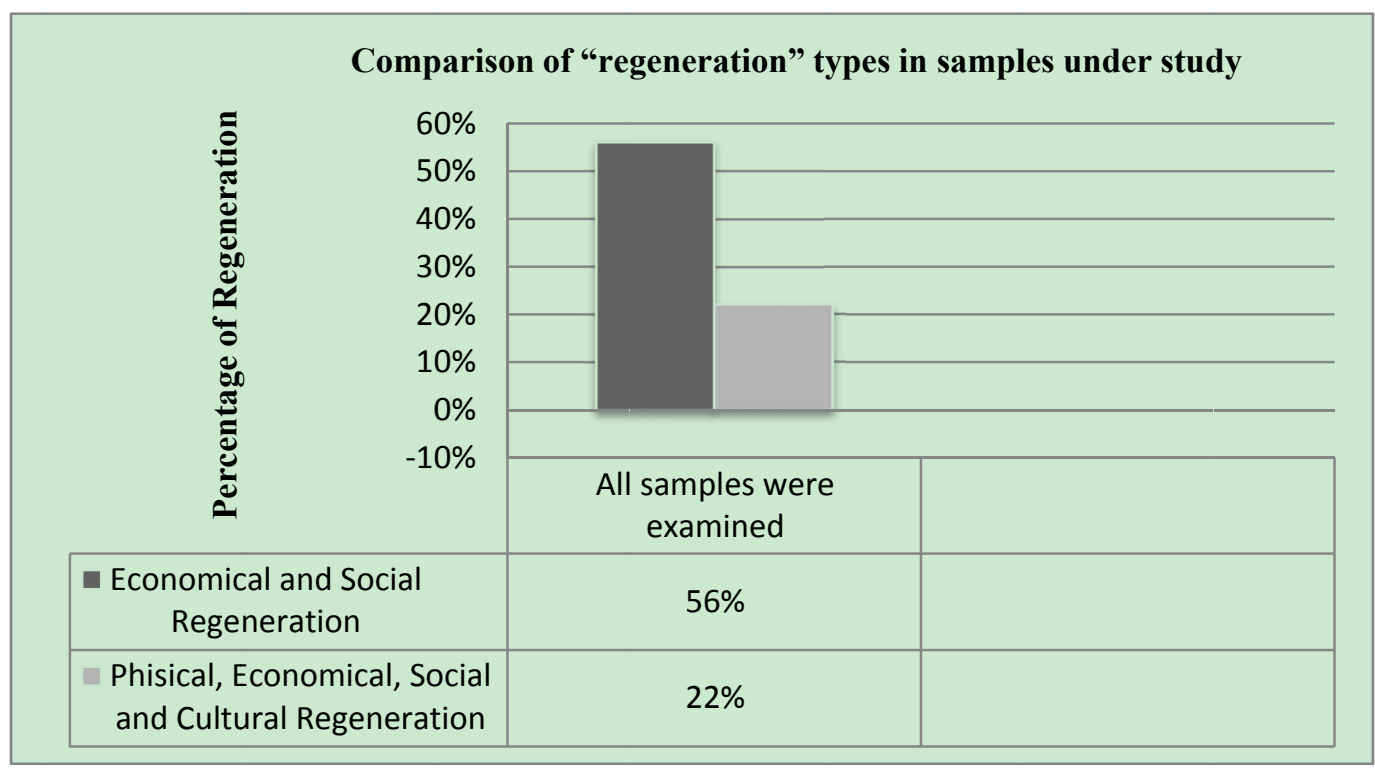

Figure 2. Comparison of "regeneration" types in samples under study

\section{Review of the Case Samples Innovated in Shiraz Town, Iran}

Shiraz town is located in Iran and has a rich cultural background. Also, it has many historical fabrics. Therefore, regeneration of the historical urban fabric of Shiraz is reviewed here.

6.1 Restoration of Shiraz Cultural - Historical Fabric, Regeneration and Reconstruction of the Sang-e-Siah Axis

The important potential of the quarter is the presence of 30 valuable historical monuments in it. Also, it is the link between two significant, highly populated quarters. Regeneration, reconstruction and renovation have been carried out for the quarter. The significant objectives in restoration of the quarter consist of economic, social, cultural and religious objectives. The physical- spatial solutions being used for regeneration of this historical quarter include:

- Regularization and establishment of Abolfazl Masque's population using Bibi Dokhtaran Shrine

- Reconstruction and restoration of Bibi Dokhtaran Shirne

- Reconstruction and restoration of Forough-al-Molk compound and creation of a museum and the house of artists 
- Body- centered improvement

- Regeneration of small traditional bazaars

- Freeing the space in front of Moshir Mosque

- Regeneration of the sculpturing and reconstruction of Armenians Bazaar, and Saint Mary's Church

6.2 Restoration of the Shiraz Cultural- Historical Fabric, Reconstruction of Astaneh Quarter in Shiraz

This quarter has turned into a marginal quarter. Therefore, attracting people's and investors' participation was proposed towards empowering the fabric. The significant objectives of this regeneration are increasing the economic value of lands and buildings, social security, and resuming the live spirit of the town to it. The physical - spatial solutions are as follows:

- Increase in construction concentration

- Design of public spaces

- Increasing physical safety

- Regeneration of cultural and leisure - time activity

6.3 Restoration and Regeneration of the Shiraz Cultural - Historical Fabric, Regeneration of the Shiraz Karimkhani Compound

This compound makes up the backbone of Shiraz town, and is significant historically. The significant objects in regeneration of this historical compound are economic and social ones, since this regeneration could bring with it economic boom of commercial stores in the space as well as improvement in the social qualities of residential areas and tourist attraction. Physical - spatial solutions are as follows:

- Regeneration of old Gateways of Shiraz

- Spatial and biological regeneration of residential areas

- Refurbishment of the quarter's backbone

- Regeneration of Zandieh Center, with modern functions

- Regeneration of Cannon-ball square

- Creation of an urban space for people's recreation

Also, access solutions such as constructing walk ways, constructing interchanges, as well as underground parking lots are in the agenda.

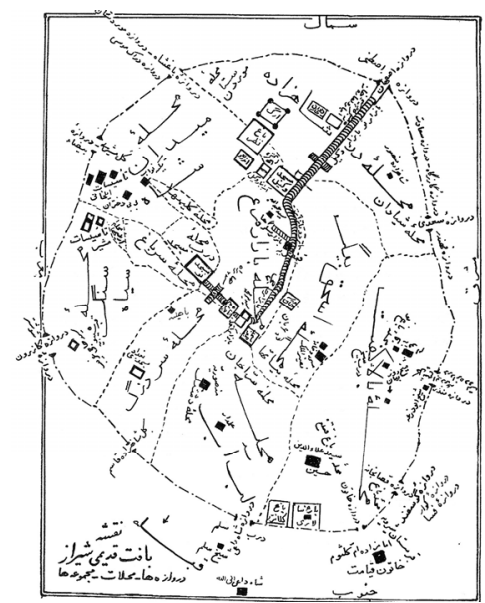

Figure 3. The situation of quarters in Shiraz old fabric

\section{The Common Element in the Process of Regeneration in Foreign and Iranian Samples Studied}

The important things are not just aesthetic or visual continuity but the continuity of memories and cultural monuments is important as well. The visible evidence from the past could help the cultural identity, preservation of people's memories and special places regarding education connect the modern community with its past tradition and make the present meaningful by linking it with the past. 
The process of regeneration and giving identity, when and if different investments are available due to high motivations, which are mostly absorbed and supported through payment of subsidies, are realized in historical quarters of the town. Regeneration and giving identity are necessary for all parts of the town, not just for those that have more prominent historical qualities and nature. Despite of this, the more the genuineness, the historical characteristic and the sense of space are available, the more the likelihood that those efforts are made toward regeneration and giving identity. In all cases, the purpose of the regeneration made, has been improvement in the function and performance of the colorful economic regeneration, the regeneration has led to a higher value added of the land, too. The following table shows this type of regeneration for the samples under study:

Table 5. Type of regeneration in the Iranian Samples under study

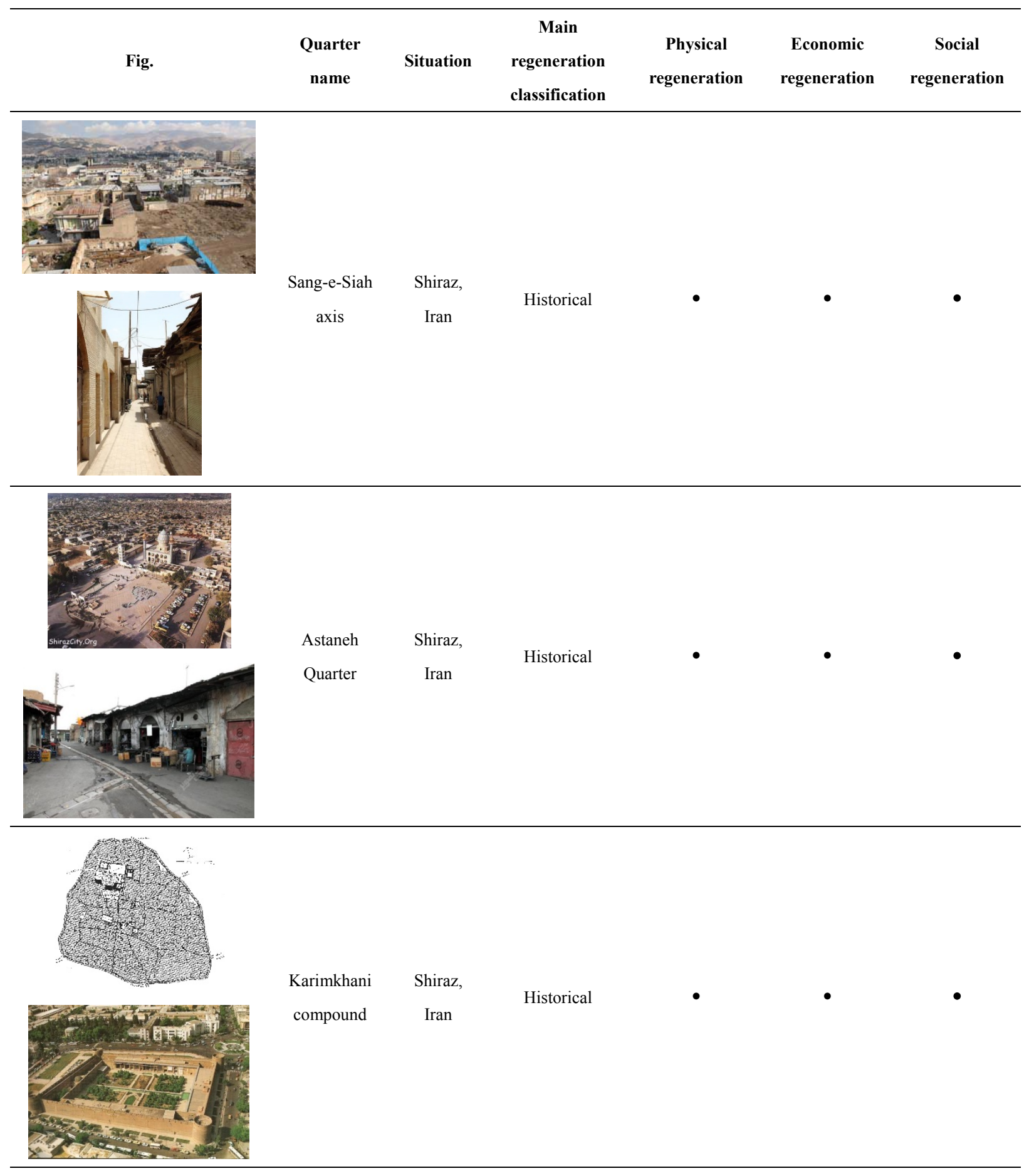




\section{Findings}

Historic quarters of towns usually have the trait of autonomous functional zones, and therefore, they could not be distinguished just based on their appearance.

They are an integral part of the functional and formal intertwinement of the central business district (CBD) and often have relations based on symbiosis with the whole city, especially its CBD. Therefore, instead of thinking about them individually, they must be considered in the general context and the whole fabric and fabric of the town and the relevant zones.

Regeneration, which is nothing but returning liveliness and activity to the zones, is a dynamic, powerful process. Taking note of the above, one could say that the process has had different degrees in different zones. A successful regeneration must also show itself in physical, economic and social aspects as well.

Table 6. Types of regeneration of the urban fabric and its characteristics

\begin{tabular}{cl}
$\begin{array}{c}\text { Type of } \\
\text { regeneration }\end{array}$ & \multicolumn{1}{c}{ Characteristics } \\
\hline $\begin{array}{c}\text { Physical } \\
\text { regeneration }\end{array}$ & $\begin{array}{l}\text { A quarter, in which successful regeneration is made, will be preserved well with desired } \\
\text { restoration: soot and pollution are removed from old buildings and buildings are improved and } \\
\text { restored. The condition of streets is improved and the total apparent scope of the town } \\
\text { becomes face lifted (example: London's Covent Garden quarter as an example of historical } \\
\text { quarters where successful regeneration has been made). }\end{array}$ \\
\hline $\begin{array}{c}\text { Economic } \\
\text { regeneration }\end{array}$ & $\begin{array}{l}\text { An innovated empty building does not add specifically anything to the strategy of the } \\
\text { economic regeneration of the area. But if the same building is occupied by tenants, it will find } \\
\text { identity. It is the people and economic activity not painting and plumbing, etc., that eventually } \\
\text { add to the economic value. }\end{array}$ \\
\hline $\begin{array}{l}\text { Social } \\
\text { regeneration }\end{array}$ & $\begin{array}{l}\text { Any historic quarter, in which successful social regeneration has been made, is a lively, happy } \\
\text { the public realm. } \\
\text { In the lowest level, there is the parking lot, which, basically no high significance is felt for its } \\
\text { presence along with the pedestrians. In the highest level, there are street markets (for example, } \\
\text { one could mention London Tames. The present challenge in creation of active. Lively urban } \\
\text { quarters are making sure that the type of uses that make up the highest interaction, are located } \\
\text { on the appropriate side of the street). }\end{array}$ \\
\hline
\end{tabular}

Iranian experiences on urban restoration explain well the depth and the scope of influence of urban restoration charters and resolutions on restoration and renovation activities of traditional and historical fabrics in different towns of Iran.

The plan for historical - cultural axes was developed during the years 1990-1992.

It was developed on three scales:

"The town and the territory - fabric and components - priority of intervention"; paying attention to the structural model of the old fabric and providing a model for linking the old backbone to the new foundation of the town is the most important thematic axis adopted in these projects. The result of this experience is structural - strategic plans for the fabric and the town as well as provision of primary models of urban design for the intervention priority. However, lack of clarity in the place and the deliverables of this process and the improper expectations from the deliverables, led to lack of fruition of the measure, such as the project for innovation of Shiraz Karim Khani Compound, The project for innovation of Hamedan Bazaar, the project for innovation of Esfahan old Square and the Atigh Jamee', no one of which could respond well to the requirements of the old urban fabric. 


\subsection{Qualitative Analysis of the Findings}

In the social realm, the most important issue is paying attention to restoration with social participation, being more valued and paid attention in developed and developing countries than Iran.

In Iran, different issues that seek after the notions of historical identity with similar items, include subjects such as preservation and retrieval of the genuine identity of the town, preservation of the historical fabric, returning the social identity of the quarter to it, etc.

Paying attention to creation of the spirit of unity among the businesses or special groups of the community of historical fabric, on the one hand, for economic considerations and, on the other hand, as a social objective, have been considered in developed countries.

In Iran, the attention has been focused more on the near future in the scope of improving the quality of life in a short time and, consequently, paying less attention to the remote future. The issue of development in different sectors, even if being noted, but has not been discussed and has been expressed less.

Providing social conditions for accepting the tourists as a significant social objective has been paid attention only in Iranian cases while in other countries it has been paid attention less in the social realm.

In the Iranian cases, a special attention has been made to the restoration of the quarter's backbone.

In developed countries, using modern technology as one of the physical solutions has been considered while it has no priority in Iran.

Consideration of cultural objectives is more common in developed countries than Iran.

Paying attention to social objectives was seen in all cases of different countries.

Economic objectives in developed countries are almost the same, but they are less common in Iranian cases.

Developed countries pay the most attention to physical issues in the projects.

Paying attention to facilities and equipments is more common in developed countries.

In both groups, developed countries and Iran, more attention is paid to physical issues while the least attention is paid to facilities issues.

For developed countries, the priorities are as follows: physical solutions, social objectives, cultural objectives and planning solutions.

For Iranian cases, priorities are as follows: physical solutions, social objectives, and planning objectives.

\section{Conclusion}

"The sense of position", "identity" and qualities that lead to uniqueness of each town for itself are among the concepts that should be considered under the title of empirical qualities of urban design. Rapoport regards urban design as organizing the space, time, meaning and communication.

The wholeness of the town has been ignored in urban design in $20^{\text {th }}$ century. Our new towns are a compound and a collection of different architectural forms. The 5000 years urban history shows that the complex fabric of alleys and squares has been a necessity for linking the districts and ultimately forming urban identity centers.

Policies and objectives such as attraction of active participation of the local people in large urban restoration projects, innovation of residential units with time, conversion of useless spaces into open public spaces, coordination in the compositions of new and old fabrics, granting new functions to the building, regularization of commercial activities, shopping centers and making recreational places, reconstruction and careful protection of the façade in the path to improvement of the structural situation of the old fabric, extensive use of water and plants in the building, demolition of buildings lacking a value, provided that the new buildings are in par with the adjacent ones, using potentials of the street, the square and the green areas texture, prevention from any damage on the foundation and organization of the old fabric, and the interaction of old elements and new spaces in the backbone of the old city are among the most important subjects, paying attention to which has been seriously made in urban restoration. Clearly, this could be regarded as the modern "Grammar" of urban restoration based on the most advanced universal experiences in the context.

Evaluation and valuation of the cultural and historical heritage regulates the past experiences and contains the spirit of design processing for the future (Carrier, 2006, p.40). Paying attention to social relations means treating the dynamism and change in the urban space. Taking into account the factor of "time" can significantly improve our understanding of the space and, consequently, our urban design works. For a more complete understanding of the space we must follow its evolution with time. Generation of the space, both in a historical vision and in the 
short-term, becomes a key to understand the space. Seeing the integration of time and space, provides us with a dynamic approach that analyzes the phenomena as they are constantly evolving and leads to a design catching up with change and for change. Excessive change and excessive pace of change will lead to separation of identities and losing control over the things and events (Madanipour, 2000, p.324). In case of continuation of lack of communication between the individual and the space, we will face an event called, "identity crisis". The first consequence of identity crisis is the fact that one finds himself as rootless. Anywhere one cannot ascribe himself to a special identity; he will feel deficient or lacking and will call himself as identity-less. Man, with imposing in the environment surrounding him, tries to prove an identity for himself. But we should not mistake one's mental belonging to a space with one's bearing an identity. Positional belonging, meaning a connection between man and environment, is among the consequences of proving one's identity and always efforts are made with time to prove that belonging. Therefore, one should note that originality does not mean absolute denial of historical identity, culture and tradition and usage of the community. Instead, originality means finding an appropriate response of the time and space to cultural values and using the ideas and experiences of the past generations and making them evolved.

Proving spatial identity has some results, the most important of which are:

1) Identification with the space: when one's subjectivity of the space turns into objectivity.

2) Spatial belonging: the interconnection between man and the environment, that sometimes goes beyond the level of emotional, cognitive and individual experiences and is tied with a common collective sense in broader spatial limits.

3) Mental belonging: when one's spatial belonging is influenced by factors such as memory in time and space and its association, it will turn into a mental belonging.

And crisis in the spatial identity occurs when the spatial identity is incompatible with the ideal identity of its bearer, so that its physical, functional and semantic characteristics carry a message and meaning that do not fit to what is expected from the place and its residents for the bearer and even for those who are around him.

Generally, one could say that in urban design, the following values should always be paid attention:

"what the people see", that is, the ability to really understand the environment; "what the people admire", that is, the ability to admire, understand and use the urban environment; "what the people can use", that is, availability and real access to urban spaces during daily activities; "what the people remember", that is, remembering good experiences of the past from urban spaces; "what the people associate", that is, the symbolic, cultural, historical and semantic aspects in urban spaces (Bahraini, 2007, p. 137).

Today, identity crisis is known as a universal crisis, one aspect of which is related to lack of identity of spaces and most spaces becoming the same form and shape. In the past, wherever the people lived, they had a sense of being rooted in the space and being dependant on it.

Therefore, these solutions are important:

1) Improvement in environmental conditions, by appropriate stress on the relation between man and environment

2) Enhancing the place of religious and historical elements and regeneration of urban environments dependant on those elements

3) Activation of social and cultural elements by designing and constructing areas appropriate for people's presence and improving the participatory power of citizens in urban spaces.

4) Physical improvement of the town by paying attention to physical components of urban identity

5) Creation of cognitive and aesthetic values with the purpose of providing the readability and upgrading the mental image of the town.

\section{References}

Bahreini, H. (2007). Urban Design Process. Tehran University Press, Iran.

Colantonio, A., \& Dixon, T. J. (2011). Urban regeneration \& social sustainability: best practice from European cities. Wiley-Blackwell, UK.

Couch, C., Fraser, C., \& Percy, S. (2003). Urban Regeneration in Europe. Blackwell Science, Oxford. https://doi.org/10.1002/9780470690604

Evans, B., \& McDonald, F. (2011a). Space, place, life : learning from place 1.Routledge, New York. 
Evans, B., \& McDonald, F. (2011b). Urban identity: learning from place 2.Routledge, New York.

Jencks, C. (1991). The Language of Post Modern Architecture. Academy Editions, London.

King, A. D. (2004). Spaces of global cultures: architecture, urbanism, identity. Routledge, New York.

Lynch, K. (1960). The image of the city. M.I.T. Press, Cambridge, Mass.

Lynch, K. (1981). Good city form. M.I.T. Press, Cambridge, Mass.

Madanipour, A. (1996). Design of urban space: An inquiry into a socio-spatial process. John Wiley \& Son Ltd, New York.

Nasr, T. (2013). Components of the Physical Identity of Iranian Cities. (Ph.D) Theses in Urban Planning, Islamic Azad University, Science and Research Branch, Tehran.

Norberg-Schulz, C. (2000). Architecture: presence, language and place. Thames \& Hudson, London.

Paddison, R., \& Tiesdell, S. (2010). Urban studies: society. SAGE, Los Angeles. https://doi.org/10.4135/9781446263723

Pakzad, J. (1996). Identity and the identity of the space. Martyr Beheshti University, Iran.

Rapoport, A. (1990). History and Precedent in Environmental Design. Plenum Press, New York. https://doi.org/10.1007/978-1-4613-0571-2

Rossi, A. (1982). The Architecture of the City. The MIT Press, Mass, Cambridge.

Tallon, A. (2010). Urban regeneration in the UK. Routledge, New York.

Tiesdell, S., Oc, T., \& Heath, T. (1996). Revitalizing historic urban quarters. Butterworth-Architecture, Boston.

\section{Copyrights}

Copyright for this article is retained by the author(s), with first publication rights granted to the journal.

This is an open-access article distributed under the terms and conditions of the Creative Commons Attribution license (http://creativecommons.org/licenses/by/4.0/). 